\title{
PRELIMINARY TRIAL OF ETISUL IN THE TREATMENT OF LEPROSY
}

by N. MukerJEE, M.B.B.S., D.T.M., D.P.H.(Cal.), Officer in Charge, and S. Ghosн, м.B.B.S., D.T.м.(Cal.), D. Bact., F.D.s. (Lond.) Assistant Prof., Leprosy Research Department, School of Tropical Medicine, Calcutta.

Compound 15.688 of $\mathrm{ICI}$, which is now known as diethyl dithiosolisophthalate, ETIP or Etisul, was found to be extremely active against tuberculous infection in mouse and guinea pig (Davies and Driver 1957) ${ }^{1}$. It was also observed that when the drug was rubbed into the skin it was capable of exerting a chemotherapeutic effect in experimental tuberculosis in mice (ethyl mercaptan is considered to be released in the body after inunction of Etisul). Davies and Driver ${ }^{2}$ (1958) studied the effect of ethyl mercaptan itself on intracellular tubercle bacilli. Using a modification of Suter's method, M. tuberculosis was grown in guinea pig monocytes and human monocytes where it was found to be effective.

The first clinical report was published by Davey ${ }^{3,4}$ (1959) where he concluded that patients differ widely in the response of their infection to this drug but a dose of 3 to 6 c.c. inuncted twice weekly has been found in some patients to exert a powerful chemotherapeutic effect on the bacilli not only at the site of inunction but generally throughout the body. The chemotherapeutic effect, though powerful, is short lived, as drug resistance developed after three months. Hence it is better to give Etisul in the beginning of treatment along with a standard antileprosy drug such as DDS.

\section{Method and Materials}

Three lepromatous cases were selected for this trial and took treatment for the last six months. Previously they did not take any treatment for their skin condition and reported first to this department as fresh cases. Detailed clinical, bacteriological, immunological and histopathological study was made. Photographs were also taken. Repeated clinical examinations were made once a week and bacteriological examinations were made once a fortnight.

Etisul is a cream for inunction. In addition to diethyl dithiolisophthalate it contains also a specially scented perfume to mask the garlicky odour.

$2.5 \mathrm{~g}$. of Etisul was rubbed on alternate days over the right arm and right forearm of the patients but after the fif th application there developed papular and erythematous lesions over the right forearm in one case. The drug was then stopped for a few days and calamine lotion was applied. Later $5 \mathrm{~g}$. was rubbed twice weekly over a large non-hairy area in addition to right arm and right forearm. An 
unpleasant odour was evident during the time of application and also later through the breath.

\section{Result}

Clinically there was no improvement noticeable in any patient during this six months' trial. In spite of continuous regular treatment the clinical condition gradually deteriorated. The lesions became thicker and more erythematous. Infiltration became more extensive. Swelling of the feet and leg developed in one patient and of the hands in another. In one patient eye lesions became more extensive. No improvement was noticed on bacteriological examination. Instead of diminution of the bacteriological index, it increased gradually. Morphologically no demonstrable change in bacilli was noticeable in any case.

Table showing Result of Treatment with Etisul

\begin{tabular}{|c|c|c|c|c|c|c|}
\hline $\begin{array}{c}\text { Serial } \\
\text { No. }\end{array}$ & $\begin{array}{c}\text { Name, } \\
\text { Age, } \\
\text { Sex }\end{array}$ & Type & $\begin{array}{c}\text { Lepro- } \\
\min \\
\text { Test }\end{array}$ & $\begin{array}{c}\text { Initial } \\
\text { B.I. }\end{array}$ & $\begin{array}{l}\text { Present } \\
\text { B.I. }\end{array}$ & Clinical Improvement \\
\hline 1. & $\begin{array}{l}\text { P.B. } \\
40 \text { yrs. } \\
\text { H.M. }\end{array}$ & L2-3 & Neg & 2.0 & 3.2 & $\begin{array}{l}\text { The lesions became more } \\
\text { extensive and thicker and } \\
\text { redder. A few nodules and } \\
\text { swelling of the hands de- } \\
\text { veloped. }\end{array}$ \\
\hline 2. & $\begin{array}{l}\text { F.R. } \\
35 \text { yrs. } \\
\text { M.M. }\end{array}$ & $\mathrm{L} 2-3$ & $\mathrm{Neg}$ & 2.0 & 3.0 & $\begin{array}{l}\text { The lesions became more } \\
\text { extensive. No restoration } \\
\text { of the sensation lost. }\end{array}$ \\
\hline 3. & $\begin{array}{l}\text { M.R.S. } \\
55 \text { yrs. } \\
\text { H.M. }\end{array}$ & L2 & Neg & 2.3 & 3.1 & $\begin{array}{l}\text { Eye lesions developed. } \\
\text { Swelling of the feet and } \\
\text { leg started. }\end{array}$ \\
\hline
\end{tabular}

\section{Discussion}

It was observed by Davey that the drug may be effective in some cases and may not be so in some others. The reason is not yet known. Davey also observed that in his own series, no appreciable improvement was observed in some cases after three months or so. But it was found effective when administered along with any antileprotic drug. In our small series, no change in the number or morphology of bacilli was found during this period of six months. He found rapid decline of B.I. in a few cases within three months. However, this was not maintained subsequently unless standard drugs were added in good time. 


\section{Conclusion}

During this six months' trial with this drug alone, no appreciab!e improvement was noticed, under a method which began with a limited inunction over the right arm and forearm.

\section{Summary}

Three active lepromatous cases were treated unsuccessfully with Etisul alone.

\section{References}

1. Davies, G. E. and Driver, G. W. (1957) Brit. J. Pharmacol., 12, 434-437.

2. Davies, G. E. and Driver, G. W. (1958) Nature, 182, 4936, 644-665.

3. Davey, T. F. and Hogerzeil, L. M. (1959) Leprosy Review, 30, 61 \& 141-152.

4. Davey, T. F. and HogerzeIl, L. M. (Nov. 1958) Trans. VIIth Internat. Congr. Leprol., Tokyo, 252-259. 